\title{
Aspects of Realism in Visual and Verbal Representations
}

\author{
Tzu Yu Allison Lin \\ Gaziantep University, Gaziantep, Turkey
}

\begin{abstract}
In this article, the author reads three literary texts—Jane Austen's Pride and Prejudice, Harold Pinter's The Birthday Party, and Edith Wharton's The Age of Innocence, in order to theorise two aspects of realism in terms of visual and verbal representations. The first aspect of realism would be through physical events and movements. The second one is through the thinking process of a character. The essential point of using realism to read a text is not to see how real the description of a figure or an object is. Rather, as the author would argue, realism is to be understood as the way in which life is true to a character's condition.
\end{abstract}

Keywords: realism, language, visual, representation, narrative

\section{Introduction}

Comparing to some other narrative forms such as Impressionism or Surrealism, the term Realism comes to suggest more elements of describing what one sees, rather than what one feels. In this respect, a realistic narration is to be understood as an observation and a representation of a kind of reality, which is created in a textual form.

\section{Representing Reality}

In his Oxford Dictionary of Literary Terms, Chris Baldick defines the term Realism as a way of "writing that gives the impression of recording or 'reflecting' faithfully an actual way of life”, because this mode of writing is "based on detailed accuracy of description" (Baldick, 2008, p. 281). For instance, in his novel Crime and Punishment, Fyodor Dostoyevsky gives the readers a vivid textual representation, which comes to describe a sequence of actions after Raskolnikov kills Alyona Ivanovna, as the readers can see the details of the elements of describing —including how he "laid the axe on the ground near the dead body", how he took "the key" out of "her pocket", how to try "not to get smeared with blood", so that he can work on fitting "the keys into the chest" (Dostoyevsky,2004, p. 95). In this sequence of actions, the readers can see that somehow, realism, as a narrative style, can be defined as an art of describing.

In a literary text, even the most realistic representation has a slightest element of the imagery. It is simply because of the nature of language, as the signifier does not always come to signify the exact meaning. Or, when the readers are reading, our visualisation of the narrative can somehow indicate the meanings between the lines, or even beyond the lines.

A visualisation of a narrative, say, as true as a photographic representation, in this respect, can have the

Tzu Yu Allison Lin, Ph.D., Dept. of Foreign Language Education, Faculty of Education, Gaziantep University, Gaziantep, Turkey. 
imaginary in a realistic description. For example, in The Old Curiosity Shop, Charles Dickens's verbal portrayal of Little Nell is extremely "vivid" (Underwood, 2012, p. 91). Although it is descriptive, this character reveals the way in which the imagery stays in a "fairy-like quality" of a girl, as she is "so fair, with such blue veins and such a transparent skin, and such little feet” (Underwood, 2012, p. 91).

Again, for example, in John Galsworthy's The Man of Property, the "soft persuasive passivity” (Galsworthy, 1994, p. 202) of Irene's face, somehow, in the eyes of the beholder Bosinney, with appreciation and love, has a “sensuous purity” (Galsworthy, 1994, p. 202) of Titian’s painting. The way in which Galsworthy depicts Irene’s face indicates the reality of "beauty adorned" (Barolskey, 1998, p. 25). Her beauty is the sacred and the 'naked truth’ (Barolskey, 1998, p. 25), with Bosinney’s recognition.

If we want to analyse Jane Austen's Pride and Prejudice in terms of realism, including verbal representations and the artistic elements in them, for example, there are at least three research aspects to be focused. First of all, we can look into the material aspects in Austen's writing, as a Marxist critic would do, in order to see the way in which the sense of reality comes to construct the material world. Most of the time, the characters talk about marriage, money and property, just as the first sentence of the novel comes to show, as "a truth universally acknowledged"- "a single man in possession of a good fortune must be in want of a wife" (Austen, 1994, p. 5). This sentence directly depicts a kind of social reality, in which marriage needs to be proposed by a rich single man. As for a woman will take that proposal into consideration or not, which will depend on the social and the financial stability of a man.

Secondly, particularly in Pride and Prejudice, a character's sense of reality is illuminated through "prejudice"-which is a kind of illusion created by misreading and misjudging people (although such a need of reading and judging people is based on an aim of another reality-marriage). The process of misreading and misjudging people, in a way, leads the characters to find the truth. Although it is not necessary to follow Tolstoy's exact way of distinguishing a good work of art, or a bad work of art (as good women are mothers, and bad women are prostitutes, see Tolstoy, 1995, p. 150), still, when the character finds his or her own true love, it proves that the process of misreading and misjudging is totally worth it. It feels just like seeing the beauty of a real work of art, with its “authenticity” (Benjamin, 1968, p. 220) and its “aura” (Benjamin, 1968, p. 221). We can certainly feel the aura of that work of art, through Benjamin's smoke. It is like Mr Darcy himself, in Chapter 7, looking at Elizabeth (after her long walk, coming to see her sister Jane), he sees something real in her not her dirty dress, but her courage and "her complexion” (Austen, 1994, p. 28).

Thirdly, in Austen's narrative, especially in Pride and Prejudice, we can tell that the way of depicting a character can be termed as psychological realism, because in some ways, Austen's narrative makes the readers think about Henry James's Isabel, in The Portrait of a Lady. As Ian Watt claimed in his The Rise of the Novel, the readers would notice the importance of the "psychological closeness to the subjective world of the characters" (Watt, 2000, p. 297). In Jane Austen’s novels, the readers can see that

there is usually one character whose consciousness is tacitly accorded a privileged status, and whose mental life is rendered more completely than that of the other characters. In Pride and Prejudice (published 1813), for example, the story is told substantially from the point of view of Elizabeth Bennet, the heroine; but the identification is always qualified by the other role of the narrator acting as dispassionate analyst, and as a result the reader does not lose his critical awareness of the novel as a whole. (Watt, 2000, p. 297) 
Austen's Elizabeth Bennet is definitely the main character, although she is not Mrs Bennet's favorite daughter. And yet, I would argue that we can hardly say that "the story is told substantially from the point of view of Elizabeth Bennet”, as Watt claimed. In Pride and Prejudice, each character in the family is equally important. The whole novel represents a society, in a way which a woman's happiness is based on how effective her "husband-hunting” business (Woolf, 1979, p. 110) can be. It seems to be very narrow, as a subject for a novel. And yet, the emotions of each character-happiness, sadness, and so on-as aspects of representing realism, come to make a balance between and among each character's— such as husband and wife, father and daughters, mother and daughters, and among the daughters, creating the beauty of Austen's narrative.

\section{Verbal Representations}

In Pride and Prejudice, a realistic representation comes in a verbal form, which is a letter written by $\mathrm{Mr}$ Darcy. The best example would be this private letter in Chapter thirty-five, which Mr Darcy wrote to Elizabeth. In the letter, Mr Darcy hoped to tell Elizabeth “the truth” (Austen, 1994, pp. 155, 158) that she deserves to know, regarding her elder sister's relation with Bingley and Mr Wickham's personality. For Mr Darcy, this letter is “a faithful narrative” (Austen, 1994, p. 158), in a way which people, events, time, places and objects (including the amount of money) are clearly stated, in order to give Elizabeth a better understanding of who he really is.

Austen's way of dealing with "the problem of reality" (Brown, 1981, p. 233) can be seen in this particular verbal form, because for Elizabeth, Mr Darcy’s letter certainly shows a kind of reality, in a way which she would know the truth, and she would realise her own feeling for Mr Darcy, as she had never found it before. The "process of vision" that Henry James depicted so much in detail, in Isabel Archer in The Portrait of a Lady, known as psychological realism ("window of perception”, in Lin, 2014, p. 93), somehow can be seen as a further development of this initial personal reality, as "the mind seeks when it wants truth" (Slattery,1972, p. 61).

In Harold Pinter's play, The Birthday Party, the readers can see another form of realism, in a way which language is used to possess nature, showing a real status of life rather than simply describe it directly. To have a birthday party for Stanley is Maggie's way of personalizing her female nature, in verbal forms, as she did not physically give birth to Stanley. Also, the date she chose was not his birthday. And yet, because of Maggie's desire of personalizing nature, after the birthday party, Stanley has a symbolic rebirth, by physically leaving the boarding house, which shows the subversion of social codes, in the realm of semiotics.

Again, the personification of nature comes to define and to highlight realism not only as a methodology of literary writing, but also as a sign of social code. In Pinter's The Birthday Party, Mccann and Goldberg can be seen as two strangers who are, in Walter Benjamin's sense in his essay “The Storyteller: Reflections on the Works of Nikolai Leskov' - two storytellers, mastering the "craftsmanship” of "storytelling” (Benjamin, 1968, p. 92). Both of them come from an unknown place, travel to Maggie's boarding house. They seem to be able to verbally construct Stanley's mysterious past. And yet, after that fake birthday party of Stanley's, in Act Three, these two storytellers come out with even more skillful verbal seductions, trying to take Stanley away from Maggie's boarding house, as

[t]hey begin to woo him, gently and with relish. During the following sequence Stanley shows no reaction. He remains, with no movement, where he sits. 
Mccann. Out of our own pockets.

Goldberg. It goes without saying. Between you and me, Stan, it’s about time you had a new pair of glasses.

Mccann. You can't see straight.

Goldberg. It's true. You've been cockeyed for years.

Mccann. Now you're even more cockeyed.

Goldberg. He’s right. You've gone from bad to worse.

Mccann. Worse than worse.

Goldberg. You need a long convalescence.

Mccann. A change of air.

Goldberg. Somewhere over the rainbow.

Mccann. Where angels fear to tread.

Goldberg. Exactly.

Mccann. You're in a rut.

Goldberg. You look anaemic.

Mccann. Rhenmatic.

Goldberg. Myopic.

Mccann. Epileptic.

Goldberg. You're on the verge.

Mccann. You're a dead duck.

Goldberg. But we can save you.

Mccann. From a worse fate.

Goldberg. True.

Mccann. Undeniable.

Goldberg. From now on, we'll be the hub of your wheel.

Mccann. We'll renew your season ticket.

Goldberg. We'll take tuppence off your morning tea.

Mccann. We'll give you a discount on all inflammable goods.

Goldberg. We'll watch over you.

Mccann. Advice you.

Goldberg. Give you proper care and treatment.

Mccann. Let you use the club bar.

Goldberg. Keep a table reserved.

Mccann. Help you acknowledge the fast days.

Goldberg. Bake you cakes.

Mccann. Help you kneel on kneeling days.

Goldberg. Give you a free pass.

Mccann. Take you for constitutionals.

Goldberg. Give you hot tips.

Mccann. We'll provide the skipping rope.

Goldberg. The vest and pants.

Mccann. The ointment.

Goldberg. The hot poultice.

Mccann. The fingerstall.

Goldberg. The abdomen belt.

Mccann. The ear plugs.

Goldberg. The baby powder.

Mccann. The back scratcher.

Goldberg. The spare tyre.

Mccann. The stomach pump.

Goldberg. The oxygen tent.

Mccann. The prayer wheel. 
Goldberg. The plaster of Paris.

Mccann. The crash helmet.

Goldberg. The crutches.

Mccann. A day and night service.

Goldberg. All on the house.

Mccann. That's it.

Goldberg. We'll make a man of you.

Mccann. And a woman.

Goldberg. You'll be re-orientated.

Mccann. You'll be rich.

Goldberg. You'll be adjusted.

Mccann. You'll be our pride and joy.

Goldberg. You'll be a mensch.

Mccann. You'll be a success.

Goldberg. You'll be integrated.

Mccann. You'll give orders.

Goldberg. You'll make decisions.

Mccann. You'll be a magnate.

Goldberg. A statesman.

Mccann. You'll own yachts.

Goldberg. Animals.

Mccann. Animals. (Pinter, 1983, pp. 92-94)

Although the above is a long quotation, we can examine the dialogue between these two "storytellers" in a more specific way. After all kinds of verbal seduction and promise of Stanley's rebirth (change the glasses, renew, re-orientated), Mccann and Goldberg conclude their verbal construction of this symbolic parenting (involving the baby powder, all day services) with the word "animals"-as comic and as shocking, if Stanley would have his yachts and would become the statesman.

The whole act of verbal construction comes to represent a perfect vision—a brilliant picture of Stanley's future. It is a whole process of being reborn, in a way which the word "animals" comes to indicate the long and harsh process of natural selection and evolution, as all animals come into their own perfect shape for survival. Although Stanley's “fog of self-fakery” (Luckhurst, 2009, p. 108) is, in a way, destroyed by the two strangers' verbal construction of a perfect picture for the future, at least it is the beginning of the whole process of being symbolically reborn.

The word "animals" in the discourse of Goldberg and Mccann would not be such a shock to the audience and the readers, if there was not any "hidden subtext" (Merritt, 1995, p. 137) as Susan Hollis Merritt terms it in her book chapter- “Some Other Language Games: Linguistic Parlays and Parleys”. I would suggest, both linguistically and dramatically, the word comes effectively to bring a very comic subversion of Stanley's dull and somehow melancholically trapped daily life, indicating that he would need not only a symbolic birthday party, but to have leave Maggie's house as a way to get rid of this madness. To be symbolically reborn, for Stanley, is to have a feeling of freedom which is just like an animal. The meaning of Stanley's re-birth comes very close to Foucault's term in his book, Madness \& Civilization. This new status means that Stanley will be free from fear or anxiety, by letting his "animality” (Foucault, 1988, p. 74) out for a change. 


\section{Visual Representations}

The best example of Austen's realism in the form of visual representation would be the portrait of Mr Darcy in the picture-gallery in Pemberley. For sure, Elizabeth knows what Mr Darcy looks like. And yet, the smile on his portrait is a significant feature, which Elizabeth knows by heart, as the portrait itself is "a striking resemblance of Mr Darcy, with such a smile over the face as she remembered to have sometimes seen when he looked at her" (Austen, 1994, p. 191).

Mr Darcy’s smile works like an epiphany for Elizabeth, as she looks at the picture. Through her gaze, at that right moment, she feels

a more gentle sensation towards the original than she had ever felt in the height of their acquaintance. The commendation bestowed on [Mr Darcy] by Mrs Reynolds was of no trifling nature. What praise is more valuable than the praise of an intelligent servant? As a brother, a landlord, a master, she considered how many people's happiness were in his guardianship!- - how much of pleasure or pain it was in his power to bestow! - how much of good or evil must be done by him! Every idea that had been brought forward by the housekeeper was favourable to his character, and as she stood before the canvas on which he was represented, and fixed his eyes upon herself, she thought of his regard with a deeper sentiment of gratitude than it had ever raised before; she remembered its warmth, and softened its impropriety of expression. (Austen, 1994, pp. 191-192)

The above paragraph reveals the way in which Elizabeth's thought and memory work with the visual object (the canvas of Mr Darcy), through the gaze. The eyes of Mr Darcy seem to be "fixed upon her" (Austen, 1994, p. 192). Gazing back, responding Elizabeth's own emotions and feelings of love and being 'graceful' (Allen, 1993, p. 37) aroused by her own gaze, Mr Darcy reveals himself in the portrait, as "a good-tempered man” and "the most generous-hearted” (Austen, 1994, p. 190) in Elizabeth’s mind. That is a very different impression from what she received in "the evening dance at Netherfield" (Austen, 1994, p. 153), as Mr Darcy was so much “misrepresented in dialogue” (Lacour, 1992, p. 616) then. Elizabeth’s epiphany, in a way, is produced through her own gaze. Her gaze refers to a deeper meaning of realism, evoking a true feeling of love. This awakening indicates the way in which "the force of love" (Amis, 2009, p. 89) comes from a real understanding of the beloved person, instead of coming from some sexual passion. This is the essence of the Austenian "insight into life" (Poggioli, 1990, p. 44), as the readers can learn from her characters and the visual representations.

In some literary texts, the meaning of realism has a stronger social perspective. The readers can see a textual representation of a particular society, in which it comes to remind the readers that even human nature sometimes comes to indicate desires which cannot be fulfilled, love can still reveal a coded world of culture and symbols, in a way which different layers of reality are represented through visual objects and figures, as Edith Wharton reminds us in her The Age of Innocence.

As I want to find out the truth—about Newland's secret love, I realise that it would only be revealed by "the level of reality”(Bowlby, 2007, p. 205) through the characters in the old New York society. Newland Archer feels that he knows May, but he does not "understand” Ellen (Wharton, 1995, p. 141), because both women come to represent two different kinds of social reality. That is the reason why Newland needs to idealise Ellen in his mind, in order to keep her as a sort of inner reality, which belongs to him. The outer reality is dominated by May, as the old New York society would show in the early 1870s. It is not only a world of nostalgic and abstract, but also “ironical and tender" (Lee, 2007, p. 561), as it is full of social meanings in terms of reading a textual world of reality. 
Wharton's realism can be seen in two aspects. Firstly of all, it is a more like a kind of literary style which depicts the visible world in detail. For instance, the way of "telling detail-the cut of Ellen Olenska's dress at the opera” (Penelope, 1990, p. 29), as Penelope claims in Edith Wharton and the Art of Fiction. Ellen's Europe is a visible world of "publicity, luxury, and glamor" (Montgomery, 1998, p. 133). In the novel, that world is depicted by Ellen herself, as a world of visual displays, which is for her, comes to represent "hell”- “on the material side" (Wharton, 1995, p. 131). Among other things, "[j]ewels—historic pearls” (Wharton, 1995, p. 131) are definitely the centre pieces of display, as the readers can see in David Bailly’s Still Life (1651, in Alpers, 1983, p. 104). Visual objects are used to represent the process of understanding the world. The painting shows the viewers a “description’ (Alpers, 1983, p. 109) of “a catalogue: wood, paper, glass, metals, stone, plaster, clay, bone, hide, earthenware, pearls, petals, water, smoke, and paint” (Alpers, 1983, p. 103). Through this painting, the readers can see that Ellen, as a woman, is seen as an object for display in Europe. Although there is no further description about that visible world, somehow, she is fully aware of that, as the readers can see the way she feels about being in that world-a world that she was trying to escaped from.

Secondly, to read realism in Wharton's own term, the readers can see that realism is used and recognised more like a writing technique, in order to "see life whole" (Wharton, 1925, p. 64), which is shown through an artistic "atmosphere” (Wharton, 1925, p. 64). In the novel, these two aspects of realism are expressed in Newland Archer's life — as the first one shows the way in which he looks at the visible world, and the second one indicates how he constructs an inner reality, which is true and real to him, in terms of the meaning of love and marriage.

For Newland, marrying May is a conscious and preferable choice, because May

had fulfilled all that he had expected. [...]. As for the momentary madness which had fallen upon him on the eve of his marriage, he had trained himself to regard it as the last of his discarded experiments. The idea that he could ever, in his senses, have dreamed of marrying the Countess Olenska had become almost unthinkable, and she remained in his memory simply as the most plaintive and poignant of a line of ghosts. (Wharton, 1995, p. 168)

As Newland cannot marry Ellen, everything about her is more real in his mind. Ellen, physically in the visible world, is away from him. They cannot be together, because it is socially unacceptable, in terms of the world of old New York.

Ellen's absence, as a part of Newland's psychological status, makes him feel "more real” (Wharton, 1995, p. 284) to him. If he goes upstairs to see Ellen, in Paris, he would be feeling like looking at a fake painting, (or a reproduction of a work of art), simply because of the "rich atmosphere" (Wharton, 1995, p. 282) - the aura of Newland's inner reality—would be gone. Newland can only "gaze at” (Wharton, 1995, p. 283) Ellen’s balcony, and "pictur[e]" (Wharton, 1995, p. 283) the way in which Ellen would be in his mind. Newland's mental picture of Ellen comes to reveal a status of his reality. He feels very happy, as his gaze represents a status which is more real than the visuality.

Ellen's figure, although visually available to Newland, represents something that he can never reach, as long as he is in the context of old New York's social reality. Only when the visual turns into the inwardness, Newland is able to hold on to the mental image. By doing so, he can keep living as the way in which the old New York society accepts—such as “a kind of innocent family hypocrisy” (Wharton, 1995, p. 274). May's first photo shows that for Newland, she represents something, which feels just like the old New York itself-“so lack of imagination, so incapable of growth, that the world of her youth had fallen into pieces and rebuilt itself without 
her ever being conscious of the change" (Wharton, 1995, p. 274). Newland is someone who fits in—as "a good citizen" (Wharton, 1995, p. 273). In old New York, it takes someone like Newland to show that marriage is not only "a dull duty” (Wharton, 1995, p. 273), but an art of keeping "the dignity of a duty” (Wharton, 1995, p. 273).

Through representing two types of women, Edith Wharton depicts her dual realism—one is Newland's “actual life” (Wharton, 1995, p. 210), representing through May, "in the house” (Wharton, 1995, p. 74); the other is Newland's "real life” (Wharton, 1995, p. 210), representing through Ellen, “a kind of sanctuary” (Wharton, 1995, p. 210) that is "within himself" (Wharton, 1995, p. 210). The more Newland's reality goes toward the inwardness, the more that reality would escape from the realm of a simple and a direct description of the visible world.

\section{Conclusion}

I explore two different types of realism through reading a few narrative forms as textual representations. First of all, in some writings, one type of realism comes from the visible world. Secondly, in some other writings, another type of realism comes from language. Although these two literary forms have a different focus in terms of certain ways of depicting the way in which what reality means, both types of realism, as I would argue in this research, would show the readers the real status of life of the characters, as they are in their textual representive worlds.

\section{References}

Allen, D. W. (1993). Sexuality in victorian fiction. Norman: University of Oklahoma Press.

Alpers, S. (1983). The art of describing: Dutch art in the seventeenth century. Chicago: The University of Chicago Press.

Amis, M. (2009). Force of love: Pride and Prejudice by Jane Austen. In S. Carson (Ed.), A truth universally acknowledged: 33 reasons why we can't stop reading Jane Austen (pp. 45-56). London: Penguin.

Austen, J. (1994). Pride and prejudice. London: Penguin.

Barolskey, P. (1998). Sacred and profane love. Source: Notes in the History of Art, 17.3, 25-28.

Benjamin, W. (1968). Illuminations: Essays and reflections. H. Arendt, (Ed.). (H. Zohn, Trans.). New York: Schocken.

Bowlby, R. (2007). Freudian mythologies: Greek tragedy and modern identities. Oxford: Oxford University Press.

Brown, M. (1981). The logic of realism: A Hegelian approach. PMLA, 96.2, 224-241.

Baldick, C. (2008). Realism. Oxford dictionary of literary terms (3rd ed.). Oxford: Oxford UP.

Dostoyevsky, F. (2004). Crime and punishment. C. B. Jobnson, (Ed.). New York: Simon \& Schuster.

Foucault, M. (1988). Madness \& civilization: A history of insanity in the age of reason. (R. Howard, Trans.). New York: Vintage.

Galsworthy, J. (1994). The man of property. Hertfordshire: Wordsworth.

Lacour, C. B. (1992). Austen's Pride and Prejudice and Hegel's “Truth in Art”: Concept, reference, and history. ELH, 59.3, 597-623.

Lee, H. (2007). Edith Wharton. London: Chatto \& Windus.

Lin, T. Y. A. (2014). A moment of joy: Essays on art, writing, and life. Taipei: Showwe.

Luckhurst, M. (2009). Speaking out: Harold Pinter and freedom of expression. In P. Raby (Ed.), The Cambridge companion to Harold Pinter (105-120). Cambridge: Cambridge University Press.

Merritt, S. H. (1995). Pinter in play: Critical strategies and the plays of Harold Pinter. Durham, NC: Duke University Press.

Montgomery, M. E. (1998). Displaying women. London: Routledge.

Penelope, V.-F. (1990). Edith Wharton and the art of fiction. New York: St. Martin's.

Pinter, H. (1983). Plays: One. London: Methuen.

Poggioli, R. (1952). Dostoevski and western realism. The Kenyon Review, 14.1, 43-59.

Slattery, M. F. (1972). What is literary realism? The Journal of Aesthetics and Art Criticism, 31.1, 55-62.

Tolstoy, L. (1995). What is art? (R. Pevear \& L. Volokhonsky, Trans.). London: Penguin. 
Underwood, H. (2012). Dickens subjects in Victorian art. In M. Bills (Ed.), Dickens and the artists (69-109). New Haven: Yale University Press.

Watt, I. (2000). The rise of the novel. London: Pimlico.

Wharton, E. (1925). The writing of fiction. London: Charles Scribner's Sons.

Wharton, E. (1995). The age of innocence. Cambridge: Cambridge University Press.

Woolf, V. (1979). Women and writing. M. Barrett, (Ed.). Orlando: Harcourt Barce. 